\title{
Chemical attributes of an Argisoil of the Vale do São Francisco after melon growth with phosphate and potash rocks biofertilizers
}

\author{
Newton P Stamford ${ }^{1}$; Patrícia M Moura ${ }^{1}$; Mário A Lira Júnior ${ }^{1}$; Carolina Etienne de RS Santos ${ }^{1}$; Luíza \\ Helena Duenhas'; Carlos Alberto T Gava ${ }^{2}$ \\ ${ }^{1}$ UFRPE-Depto. Agronomia, Dois Irmãos, 52171-900 Recife-PE; ${ }^{2}$ Embrapa Semi-Árido, C. Postal 23, 50171-900 Petrolina-PE; new- \\ tonps@depa.ufrpe.br
}

\begin{abstract}
Fertilizer application may promote significant changes in soil reaction and on the availability of important nutrients for plants. The utilization of rock biofertilizers is a practical process that reduces energy consumption and increases nutrient availability in soils. In a field experiment, the effect of biofertilizers produced with phosphate and potash rocks plus Acidithiobacillus inoculation were evaluated on the chemical attributes of an Argisoil from the São Francisco Valley, Pernambuco State, Brazil, after melon cultivation. The experiment was arranged in a factorial $3^{2}+2$ scheme in randomized block design, with four replicates. Two sources of $\mathrm{P}$ biofertilizer (PB) and $\mathrm{K}$ biofertilizer $(\mathrm{KB})$ were applied in the same doses recommended for simple superphosphate (SS) and potassium chloride $(\mathrm{KCl})$, and in doses which corresponded to two and three times the recommended ones. Additional treatments were carried out (soluble fertilizers (SS) and potassium chloride $\mathrm{KCl}$ ), applied in the recommended dose, and control treatment with no addition of $\mathrm{P}$ and $\left.\mathrm{K}\left(\mathrm{P}_{0}+\mathrm{K}_{0}\right)\right)$. Biofertilizers reduced soil $\mathrm{pH}$ and higher available $\mathrm{P}$ and $\mathrm{K}$ values were obtained when higher doses of biofertilizers (PB and $\mathrm{KB}$ ) were applied. $\mathrm{Mg}$ content increased when $\mathrm{KB}$ biofertilizers were applied in higher rates, probably due to the solubilization of $\mathrm{Mg}$ present in the biotite. The rock biofertilizers with Acidithiobacillus may be recommended as an alternative to soluble fertilizers by the residual effect in nutrient availability, especially in sodic soils or in limed acid soils.
\end{abstract}

Keywords: Cucumis melo, Acidithiobacillus, apatite, biotite, available $\mathrm{P}$ and $\mathrm{K}$, sulfur oxidation.

\section{RESUMO}

Atributos químicos de um Argissolo do Vale do São Francisco após cultivo de melão com biofertilizantes de rochas fosfatada e potássica

A aplicação de fertilizantes pode promover mudanças na reação do solo e na disponibilidade de nutrientes importantes para as plantas. A produção de biofertilizantes a partir de rochas é um processo prático que reduz o consumo de energia e aumenta a disponibilidade de nutrientes no solo. Em experimento de campo foram avaliados os efeitos de biofertilizantes produzidos com rochas, além do enxofre elementar inoculado com Acidithiobacillus, em atributos químicos de um Argissolo do Vale do São Francisco após cultivo do melão, em comparação com fertilizantes minerais solúveis. Usou-se o fatorial $3^{2}+2$, em blocos casualizados, com biofertilizante fosfatado (PB) e potássico (KB), em quantidades correspondentes à adição de superfosfato simples (SS) e cloreto de potássio $(\mathrm{KCl})$, o dobro e o triplo da recomendação. Foram usados tratamentos adicionais com $\mathrm{SS}+\mathrm{KCl}$ na quantidade recomendada e o controle sem adição de $\mathrm{P}$ e $\mathrm{K}\left(\mathrm{P}_{0} \mathrm{~K}_{0}\right)$. Os biofertilizantes reduziram o pH do solo, e os teores mais elevados de $\mathrm{P}$ e $\mathrm{K}$ disponíveis foram obtidos com aplicação de $\mathrm{PB}$ e KB nas doses mais elevadas. Os maiores teores de $\mathrm{Mg}$ foram obtidos com o biofertilizante KB na dose $240 \mathrm{~kg} \mathrm{ha}^{-1}$, em função da liberação de $\mathrm{Mg}$ da biotita. Os biofertilizantes de rochas com P e K podem ser usados como alternativa a fertilizantes solúveis, devido ao maior efeito residual para $\mathrm{P}, \mathrm{Ca}$ e $\mathrm{Mg}$ do solo, especialmente em solos alcalinos ou para solos ácidos após a calagem.

Palavras-chave: Cucumis melo, Acidithiobacillus, apatita, biotita, disponibilidade de P e K, oxidação do enxofre.

(Recebido para publicação em 25 de abril de 2009; aceito em 13 de novembro de 2009)

(Received in April 25, 2009; accepted in November 13, 2009)

$\mathrm{F}$ ertilizers are very important to increase yield of most crops, especially in reference to phosphorus and potassium, however, the high costs of the soluble fertilizers contribute to the reduced application by low incoming farmers (Sanchez, 2002). The nutrients are not normally found in the available form in soils and, to be solubilized, these minerals need to be modified by physical, chemical or biological processes to be absorbed by plants (van Straaten, 2002, 2007).
The soluble potash fertilizers occupy a special place worldwide and in Brazilian agriculture it is the second most used. Brazil imports this fertilizer in the potassium chlorine form as much as 6 million $\mathrm{t}_{\text {year }}{ }^{-1}$. Nowadays, the Brazilian industry of potassium fertilizers produces about 650 thousand $t$ year-1 of $\mathrm{K}_{2} \mathrm{O}$ (Roberts, 2004). The rocks used to produce phosphate fertilizers are of low solubility and generally not directly applied to plant absorption due to its very low availability (van Straaten,
2002). However, the effectiveness of natural phosphates may be increased by inoculation of microorganisms used to increase phosphate solubilization (Nahas, 1999; Rodríguéz \& Fraga, 1999; Whitelaw, 2000; Stamford et al. 2006, 2007).

The use of microorganisms to increase solubilization of nutrients from rockshas been receiving more attention from the researches recently (Ballestero et al., 1996; Nahas, 1999). The sulfur oxidizing bacteria, Thiobacillus, 
recently classified as Acidithiobacillus (Kelly \& Wood, 2000) occurs naturally in soils and is the most used. These microorganisms may promote the dissolution of insoluble phosphate producing organic and inorganic acids. The mechanism of solubilization is normally the action of the acids that improves the liberation or availability of phosphate (He et al., 1996).

The microorganisms which perform the sulfur oxidation are of great importance in the solubilization of soil nutrients, especially phosphorus, potassium, calcium and magnesium. Species as $A$. thiooxidans and $A$. ferrooxidans are recognized by its relevance in the biotecnological processes (Garcia Júnior, 1992). Biofertilizers, obtained from phosphate and potash rocks by the addition of sulfur inoculated with Acidithiobacillus, are produced in field scale (Stamford $e t$ $a l ., 2007)$. The agronomic effectiveness of these products was evaluated in various Brazilian soils and economic crops as cowpea, sugar cane, lettuce, grapes and melon (Stamford et al., 2004, 2006; Andrade, 2007; Lima et al., 2007; Moura, 2006; Moura et al., 2007), with relevant results.

We evaluated the effect of biofertilizers obtained from mineral phosphate rock (apatite) and mineral rock containing potash (biotite) plus sulfur inoculated with Acidithiobacillus in on-site conditions on some chemical attributes of an Argisoil of the São Francisco Valley and the relationship with melon yield, compared to soluble mineral fertilizers.

\section{MATERIAL AND METHODS}

The bacteria Acidithiobacillus was cultivated in a specific $9 \mathrm{~K}$ medium (Garcia Junior, 1991) using a 125 $\mathrm{mL}$ Erlenmeyer with $50 \mathrm{~mL}$ of the medium. Plants were irrigated daily by conventional sprinkler irrigation, maintaining humidity near field capacity. At the end of the incubation period (60 days) the $\mathrm{pH}\left(\mathrm{H}_{2} \mathrm{O}\right)$ and the available P and K (Embrapa, 1997) were determined: $\mathrm{P}$ Biofertilizer $=\mathrm{pH} 3.3$ and available $\mathrm{P} 50 \mathrm{~g} \mathrm{~kg}^{-1} ; \mathrm{K}$ biofertilizer $=\mathrm{pH}$ 3.0 and available $\mathrm{K} 1.5 \mathrm{~g} \mathrm{~kg}^{-1}$.
The biofertilizers were produced in on-site conditions at the Universidade Federal Rural de Pernambuco, using furrows with $10 \mathrm{~m}$ in length, $1 \mathrm{~m}$ in width, and $0.5 \mathrm{~m}$ in depth, following the methodology described by Stamford et al. (2006). The phosphate rock (apatite) was purchased from Irecê, Bahia State, with $24 \%$ of total $\mathrm{P}_{2} \mathrm{O}_{5}$ and the potash rock (biotite) from Santa Luzia, Paraiba State, with $10 \%$ of $\mathrm{K}_{2} \mathrm{O}$ total, mixed with sulfur $\left(100 \mathrm{~kg} \mathrm{~kg}^{-1}\right)$ and inoculated with Acidithiobacillus. The sulfur bacteria was inoculated diluting $2 \mathrm{~mL} / \mathrm{L}$ of cultivated medium in $10 \mathrm{~L}$ of water, and pulverized in two layers, $20 \mathrm{~cm}$ deep.

At the final of both biofertilizer production (60 days of incubation), the total $\mathrm{P}$ and $\mathrm{K}$ (extracted by percloric and nitric acid methodology), the $\mathrm{P}$ and $\mathrm{K}$ solubility in water, ammonium citrate (N.C.A) and extracted by Mehlich 1 (Embrapa, 1997) were analyzed. The compound samples used for these analyzes, collected in five packages with six replicates, resulted: Biofertilizer $\mathrm{KB}\left(\mathrm{g} \mathrm{kg}^{-1}\right)($ total $)=15.0 ;\left(\mathrm{H}_{2} \mathrm{O}\right)=0.5$; $($ Mehlich 1$)=5.0$; Biofertilizer PB $($ total $)=2.7 ;$ Rocks $\mathrm{K}+\mathrm{S}(\mathrm{RP}),($ total $\mathrm{K})=$ $16.2 ;\left(\mathrm{H}_{2} \mathrm{O}\right)=0.2 ; \mathrm{P}$ biofertilizer $(\mathrm{BP})(\mathrm{g}$ $\left.\mathrm{kg}^{-1}\right),($ total $)=106 ;\left(\mathrm{H}_{2} \mathrm{O}\right)=4,0 ;($ Mehlich $1)=17,0 ;\left(\mathrm{NCA}+\mathrm{H}_{2} \mathrm{O}\right)=42,0$; Rock $\mathrm{P}+\mathrm{S}^{*}(\mathrm{RP}),($ total $\mathrm{P})=106 ;\left(\mathrm{H}_{2} \mathrm{O}\right)=0,4$; $($ Mehlich 1$)=22,0 ;\left(\mathrm{NCA}+\mathrm{H}_{2} \mathrm{O}\right)=55,0$. (*Rock $\mathrm{P}+\mathrm{S}$ represents ground rock plus $\mathrm{S}$ and Acidithiobacillus).

The field experiment was undertaken at Embrapa Semiárido, in Petrolina, Pernambuco State. The soil classified as "Gray Argissol medium texture" (Embrapa, 1999) is a characteristic soil with low available $\mathrm{P}$ and $\mathrm{K}$, predominantly cultivated with horticultural crops, cowpea legume and cotton. The climate according to the Köppen classification is 'BSwh'. The chemical and physical analyzes of soil samples collected before the fertilization treatments application, at $0-20 \mathrm{~cm}$ deep, showed the following chemical attributes: $\mathrm{pH}$ $\left(\mathrm{H}_{2} \mathrm{O}\right)=5.6$; Organic matter $\left(\mathrm{g} \mathrm{kg}^{-1}\right)=$ 12.31; Electrical conductivity (dS $\left.\mathrm{m}^{-1}\right)=0.15 ; \mathrm{P}($ Mehlich 1$)=4 \mathrm{mg} \mathrm{dm}^{-3}$; exchangeable cations $\left(\mathrm{cmol} \mathrm{dm}^{-3}\right) \mathrm{K}=$ $0.26 ; \mathrm{Ca}=1.3 ; \mathrm{Mg}=0.60 ; \mathrm{Na}=0.05$; $\mathrm{Al}=0.05$ and $\mathrm{H}+\mathrm{Al}=1.65 ; \mathrm{S}=2.18 ; \mathrm{T}=$ 3.83 cation saturation $=57 \%$. Physical attributes: particle density $\left(\mathrm{g} \mathrm{cm}^{-3}\right)=$ 2.62; bulk density $\left(\mathrm{g} \mathrm{cm}^{-3}\right)=1.66$; sand $\left(\mathrm{g} \mathrm{kg}^{-1}\right)=900$; lime $\left(\mathrm{g} \mathrm{kg}^{-1}\right)=70$ and clay $\left(\mathrm{g} \mathrm{kg}^{-1}\right)=30$.

The experiment was carried out in a factorial $3^{2}+2$ additional treatments, in randomized blocks, with four replicates. Treatments were two fertilizer sources (phosphate biofertilizer (PB) and potash biofertilizer (KB)), and three rates of fertilizer application $\left(\mathrm{kg} \mathrm{ha}^{-1}\right)$, corresponding to 1,2 and 3 times the recommended dose of $\mathrm{P}$ and $\mathrm{K}$ for irrigated melon in Pernambuco State (IPA, 2008). Based on $\mathrm{P}$ and $\mathrm{K}$ soil analyzes, the application of $100 \mathrm{~kg}$ $\mathrm{ha}^{-1}$ of SS and $80 \mathrm{~kg} \mathrm{ha}^{-1}$ of $\mathrm{KCl}$ were recommended. The additional treatments were: a) soluble mineral fertilizers (SS) and $(\mathrm{KCl})$, in recommended rates and $b$ ) the control treatment without $\mathrm{P}$ and $\mathrm{K}$ application $\left(\mathrm{P}_{0} \mathrm{~K}_{0}\right)$.

The $\mathrm{P}$ biofertilizer was applied on rates $\mathrm{PB}_{100}$, corresponding to the same amounts calculated to $\mathrm{SS}_{100}(100 \mathrm{~kg}$ $\left.\mathrm{ha}^{-1}\right), \mathrm{PB}_{200}\left(200 \mathrm{~kg} \mathrm{ha}^{-1}\right)$ and $\mathrm{PB}_{300}$ (300 kg ha-1); and $\mathrm{K}$ biofertilizer on rates $\mathrm{KB}_{80}$, applying the same amount calculated to $\mathrm{KCl}\left(80 \mathrm{~kg} \mathrm{ha}^{-1}\right), \mathrm{KB}_{160}$ $\left(160 \mathrm{~kg} \mathrm{ha}^{-1}\right)$ and $\mathrm{KB}_{240},\left(240 \mathrm{~kg} \mathrm{ha}^{-1}\right)$.

During the experimental period (90 days), the photoperiod remained set to $12 \mathrm{~h}$ of dark and $12 \mathrm{~h}$ or light. The temperature oscillated between 28 and $36^{\circ} \mathrm{C}$ and relative humidity was $60-80 \%$, resembling the natural growth conditions of this crop.

The soil was prepared for melon cultivation cutting and removing all vegetation of the experimental area and following conventional tillage with one plowing and two diskings. Later, the rows were open to melon seedlings plantation. At the same time, the respective fertilization treatments were applied. Melon was grown spaced $2.0 \times 0.5 \mathrm{~m}$ in plots with four $10 \mathrm{~m}$-length rows and $8 \mathrm{~m}$ width, corresponding to a total area of $80 \mathrm{~m}^{2}$, with 80 plants. Thirty six plants were harvested to evaluate the experimental yield. The irrigation was carried out based in the tensiometers methodology, which were installed in the soil at $20 \mathrm{~cm}$ depth and $10 \mathrm{~cm}$ of distance of the sprinkler unit (water drops), according to Sousa et al. (1999). The water tension in the soil was 
utilized to maintain the moisture near field holding capacity.

The fertilizers at the planting date were applied in rows $10 \mathrm{~m}$ length and $10 \mathrm{~cm}$ depth. The dressed fertilization was realized 5 days after seed transplantation. Nitrogen fertilizer was applied (100 kg ha-1) using urea and calcium nitrate, by fertirrigation using water drops following the Bar-Yosef (1999) methodology, adapted by Faria \& Fontes (2003). After the fruits harvest, soil samples were collected at $0-20 \mathrm{~cm}$ depth, to analyze the chemical attributes: $\mathrm{pH}$, available $\mathrm{P}$ and $\mathrm{K}$ (Mehlich 1), exchangeable sodium, calcium and magnesium, in accord to Embrapa (1997) methodology.

The statistical calculations for the field experiment were carried out with the software SAS version 8.0 (SAS Institute, 1999). Analyzes of variance and averages were compared by the Tukey test at probability $\mathrm{p} \leq 0.05$.

\section{RESULTS AND DISCUSSION}

The application of phosphate biofertilizer (PB) and potassium biofertilizer $(\mathrm{KB})$ the natural soil $\mathrm{pH}$ (pH 5.6) and lower $\mathrm{pH}$ values were obtained with application of KB in rate $\mathrm{KB}_{240}$ (Figure 1). The acidification due to application of rock biofertilizers is in accord with Villar (2003). This author suggested that the presence of the specie Acidithiobacillus thiooxidans in the sludge waste was the main factor responsible to the acidification process reducing the $\mathrm{pH}$ to values below 4.0.

Stamford et al. (2003) observed great reduction in soil $\mathrm{pH}$ when elemental sulfur was inoculated with Acidithiobacillus in the amendment of saline sodic soils. He suggested that the effect was promoted by the metabolic production of $\mathrm{H}_{2} \mathrm{SO}_{4}$ and that the acid production continues until the total consumption of the added sulfur. Probably, the bacteria may promote soil acidity reducing initial $\mathrm{pH}$ from 8.2 to 4.5 with application of elemental sulfur in the rate $1.8 \mathrm{t} \mathrm{ha}^{-1}$. Using rock phosphate (Gafsa phosphate) plus elemental sulfur with and without Acidithiobacillus inoculation, Stamford

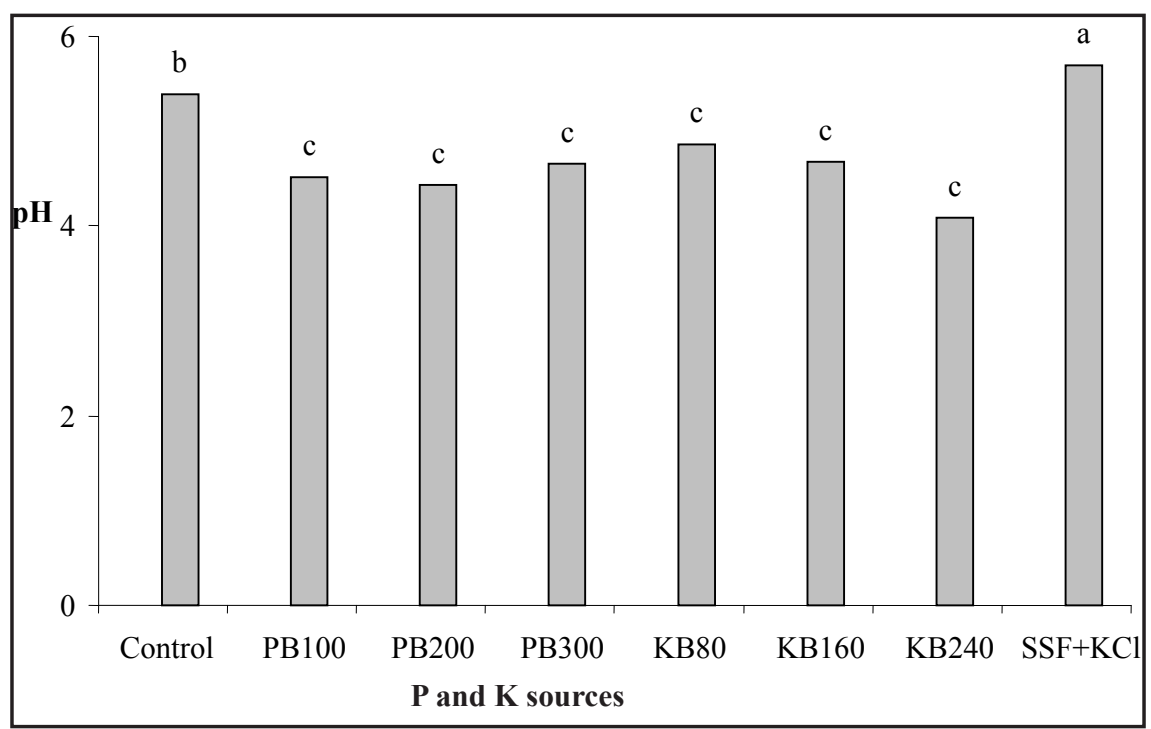

Figure 1. Effect of $\mathrm{P}$ and $\mathrm{K}$ biofertilizers on soil $\mathrm{pH}$ compared to soluble fertilizers (simple superphosphate and potassium chloride) and without $\mathrm{P}$ and $\mathrm{K}$ fertilization on melon grown in a Gray Argissol soil, medium texture, of the São Francisco region (efeito dos biofertilizantes com P e K no pH, comparado com fertilizantes solúveis (superfosfato simples e cloreto de potássio) e sem fertilização com P e K após cultivo de melão em um Argissolo Acinzentado textura média da região do São Francisco). Petrolina, UFRPE, 2008.

Values followed by the same letter are not significant by the Tukey test $(p=0.05)$; CV $(\%)=12.46$.

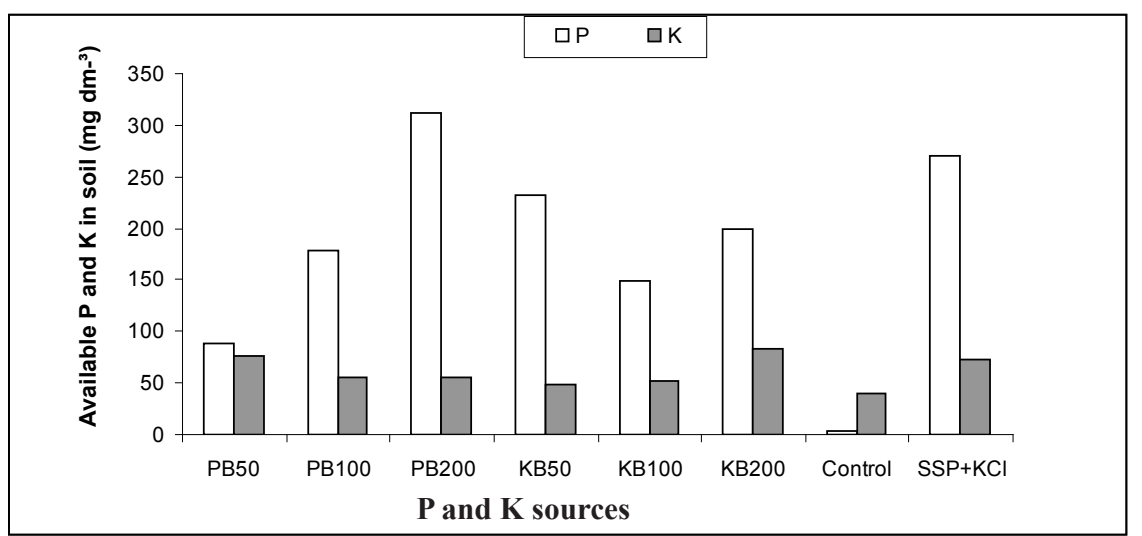

Figure 2. Effects of $\mathrm{P}$ and $\mathrm{K}$ biofertilizers on available $\mathrm{P}$ and $\mathrm{K}$, compared to soluble fertilizers (simple superphosphate and potassium chloride) and without $\mathrm{P}$ and $\mathrm{K}$ fertilization on melon grown in a Gray Argissol soil, medium texture, of the São Francisco region (efeito dos biofertilizantes com $\mathrm{P}$ e K no $\mathrm{P}$ e $\mathrm{K}$ disponíveis, comparado com fertilizantes solúveis (superfosfato simples e cloreto de potássio) e sem fertilização com P e K após cultivo de melão em um Argissolo Acinzentado textura média da região do São Francisco) Petrolina, UFRPE, 2008.

Values followed by the same letter are not significant by the Tukey test $(\mathrm{p}=0,05)$; available $\mathrm{P}=25.93$; available $\mathrm{K}=21.80$.

et al. (2005) confirmed the soil $\mathrm{pH}$ reduction in a sodic soil cultivated with mimosa (Mimosa cesalpiniifolia); the decreasing in $\mathrm{pH}$ was observed with and without inoculation, but the effect was more pronounced with the application of the sulfur oxidizing bacteria. Lima et al. (2007), in a field experiment, applied rates of $\mathrm{P}$ and $\mathrm{K}$ rock biofertilizers with Acidithiobacillus in a soil of Ceará State (Cariri Region) cultivated with lettuce and described no significant effect in soil $\mathrm{pH}$ reduction. This result was obtained probably due to the application of the KB rock biofertilizer mixed with earthworm compound with a $\mathrm{pH}$ up to 
7.8. The acidity of the rock biofertilizers produced by Acidithiobacillus can be neutralized through soil liming, or mixing organic matter with high $\mathrm{pH}$ to the biofertilizers (Stamford et al., 2005, 2006).

Application of phosphate biofertilizer on rate $\mathrm{PB}_{300}$ resulted in greater values of available $\mathrm{P}$ in soil, showing significant effect when compared to soluble mineral fertilizers $(\mathrm{SS}+\mathrm{KCl})$ that showed low available $\mathrm{P}$ in soil (Figure 2). These results evidenced the effect of the sulfur oxidizing bacteria on $\mathrm{P}$ availability, and it is possible that the rock biofertilizer promotes higher residual effect after the first melon crop, due to the very high values of available $P$ in soil when $P$ biofertilizer was applied. The available $\mathrm{P}$ in the soluble mineral fertilizer (SS) probably was absorbed by the plant roots and, due to the high sand content of the soil and to the intensive rains occurred during the experimental period, probably the nutrients were percolated, including the $\mathrm{P}$ from the soluble mineral fertilizer. The results of melon yield have been presented by Moura et al. (2007), but a closed and significant correlation was observed between available P (Mehlich 1) and melon yield grown in the Argissoil (Table 1).

Some authors affirmed that the Mehlich 1 method may extract more $\mathrm{P}$ when rock phosphate was used in analyzes. In a study interpreting the results of 360 soil samples (Giordane \& Gianelo, 2008), comparing many soil extractors, a very high and significant correlation coefficient was obtained, using the Mehlich 1 method; only Mehlich 3 method needed adjustments when clay soils were used to present increase in P extracted. Dias et al (2005) found a close correlation between the evaluation methods of available $P$ in soils, including the biological method with Aspergillus sydowii. Santos (2002), in a study evaluating some extractors (Mehlich 1, Mehlich 3, Bray 1) to determine available $\mathrm{P}$ after application of different sources (rock phosphate, $\mathrm{P}$ rock biofertilizer and soluble mineral fertilizer (SS)) showed a high coefficient of correlation between the different extractors with plant biomass.

Stamford et al. (2005), studying

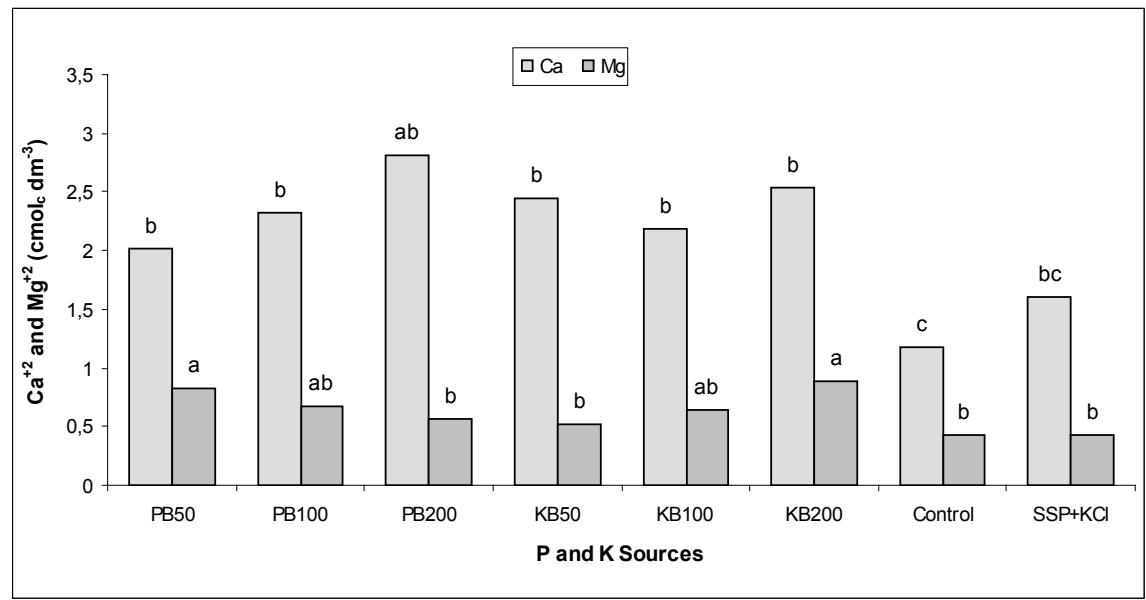

Figure 3. Effects of $\mathrm{P}$ and $\mathrm{K}$ biofertilizers on exchangeable $\mathrm{Ca}^{+2}$ and $\mathrm{Mg}^{+2}$, compared to soluble fertilizers (simple superphosphate and potassium chloride) and without $\mathrm{P}$ and $\mathrm{K}$ fertilization on melon grown in a Gray Argissol soil, medium texture, of the São Francisco region (efeito dos biofertilizantes com $\mathrm{P}$ e $\mathrm{K}$ no $\mathrm{Ca}^{+2}$ e $\mathrm{Mg}^{+2}$ trocáveis, comparado com fertilizantes solúveis (superfosfato simples e cloreto de potássio) e sem fertilização com $\mathrm{P}$ e K após cultivo de melão em um Argissolo Acinzentado textura média da região do São Francisco). Petrolina, UFRPE, 2008.

Values followed by the same letter are not significant by the Tukey test $(\mathrm{p} \leq 0.05) ; \mathrm{Ca}^{+2}=21.78$; $\mathrm{Mg}^{+2}=20.57$.

Table 1. Coefficient of linear correlation between melon productivity and applied $\mathrm{P}$ and $\mathrm{K}$ in soil, as $\mathrm{P}$ biofertilizer (PB), K biofertilizer $(\mathrm{KB})$, soluble mineral fertilizer (FP+FK) and the control treatment with no $\mathrm{P}$ and $\mathrm{K}$ fertilizer applied $\left(\mathrm{P}_{0} \mathrm{~K}_{0}\right)$ (coeficiente de correlação linear entre a produtividade do melão e $\mathrm{P}$ e $\mathrm{K}$ aplicados no solo, como biofertilizante de $\mathrm{P}(\mathrm{PB}) \mathrm{e}$ biofertilizante de $\mathrm{K}(\mathrm{KB})$, fertilizante mineral solúvel ( $\mathrm{FP}+\mathrm{FK})$ e o tratamento testemunha sem fertilizante de $\mathrm{P}$ e $\mathrm{K}$ aplicados $\left(\mathrm{P}_{0} \mathrm{~K}_{0}\right)$ ). Petrolina, UFRPE, 2008.

\begin{tabular}{lc}
\hline Correlation & Coefficient (r) \\
\hline $\mathbf{K}_{\mathbf{0}} \mathbf{P}_{\mathbf{0}}$ & \\
Productivity x P & $-0,975^{*}$ \\
Productivity x K & $-0,993^{*}$ \\
FP+FK & \\
Productivity x P & $0,853^{*}$ \\
Productivity x K & $0,809^{*}$ \\
BP+BK & \\
Productivity x P & $0,925^{*}$ \\
Productivity x K & $0,839^{*}$ \\
\hline
\end{tabular}

$\mathrm{Ns}=$ not significant $(\mathrm{p} \leq 0.05) ;{ }^{*}$ significant $(\mathrm{p} \leq 0.05)$.

the use of rock phosphate pelleted by sulfur inoculated with Acidithiobacillus in a Typic Fragiudult soil of the Humid Zone of Pernambuco, Brazil, grown with mimosa (Mimosa caesalpiniifolia), described a significant effect of available $\mathrm{P}$ in soil, and higher effect in comparison to the application of soluble mineral phosphate (SS). Moura (2003), evaluating yambean (Pachyrhizus erosus) and cowpea, described that the application of apatite mixed with SS and inoculated with Acidithiobacillus increased the disponibility of P. Stamford et al. (2007) evaluating yambean fertilized with apatite and SS observed high correlation for disponible P using Mehlich 1 method.

Lombardi et al. (1981) suggested that, due to the low concentration of sulfur in soils, the population of Acidithiobacillus is limited but, on 
the other hand, the application of this element may improve the number of cells of the sulfur oxidizing bacteria and phosphorus availability and, consequently, increase the $\mathrm{P}$ absorption by the plant.

Nahas (2002), studying the effect of soluble mineral fertilizers (SS), observed a significant increase of the population of bacteria that produce alkalyne phosphatase in relation to addition of powdered natural phosphate. This fact may be explained by the higher residual effect of the $\mathrm{P}$ biofertilizer, compared to a soluble mineral fertilizer, because the sulfur oxidizing bacteria Acidithiobacillus continuously produces acid contributing to an increasing of the acidity and $\mathrm{P}$ solubilization. This is in accord with He et al. (1996), who suggested that acidity is the most important factor to promote $\mathrm{P}$ solubilization.

Lombardi (1981) described the effect of application of "Alvorada" natural phosphate with and without addition of S inoculated with Acidithiobacillus, even in the development of forage grasses and in total $\mathrm{P}$ uptake, by the oxidizing bacteria inoculation. Similar results were obtained by Santos (2002) and Stamford et al. (2003) who observed positive and significant effect on total $\mathrm{P}$ uptake in shoot and in the $P$ available in soil, when Gafsa natural phosphate was applied plus elemental S inoculated with Acidithiobacillus. Stamford et al. (2004) verified the $\mathrm{P}$ biofertilizer from rock phosphate plus sulfur inoculated with Acidithiobacillus, either in total P uptake by cowpea plants and in Available P in soil and showed higher values compared to application of SS, on a coastal tableland soil of Pernambuco.

Despite of this fact it may be possible that soil microorganisms, including bacteria and fungi, have the ability to solubilize phosphate by several mechanisms, especially acid production (Sperber, 1958; Banik \& Dey, 1982; Kucey, 1983; Nahas, 1999; Rodríguez \& Fraga, 1999; Whitelaw, 2000). Silva Filho \& Vidor (2000), studying the phosphate solubilization by microorganisms, observed increase of $P$ availability from natural phosphate and acid production, and they agree that this may be the most important mechanism to improve available $\mathrm{P}$ in soil.

The available potassium in soil increases when mixed soluble mineral fertilizers $(\mathrm{SS}+\mathrm{KCl})$ are applied, probably due to the higher concentration of potassium in the soluble mineral fertilizer $(\mathrm{KCl})$, followed by the treatment with potassium biofertilizer (KB) in the rate $\mathrm{KB}_{240}$ (Figure 2). It is important to know that there are not many references about application of potassium biofertilizers produced from powdered rocks. In soils of the coastal tableland of Pernambuco State, after sugar cane cultivation, Stamford et al. (2006) described increasing availability of $\mathrm{K}$ in soil when $\mathrm{K}$ rock biofertilizer plus elemental sulfur inoculated with Acidithiobacillus were applied, similar to the results found in the present study with melon. Lima et al. (2007) verified positive and signifcant effect of $P$ and $\mathrm{K}$ fertilization in available $\mathrm{K}$ in soil, after lettuce crop in the region of Cariri, and the best results were obtained when $\mathrm{KCl}$ was applied at $160 \mathrm{~kg} \mathrm{ha}^{-1}$, and with $\mathrm{K}$ rock biofertilizer $(\mathrm{KB})$ in the rate $\mathrm{KB}_{80}$.

The effect on exchangeable calcium was greatest and with enough evidence in the treatments in which $\mathrm{P}$ biofertilizer was applied in a higher rate $\left(\mathrm{P}_{300}\right)$, as showed in Figure 3. The soluble mineral fertilizer $(\mathrm{SS}+\mathrm{KCl})$ and the control treatment showed the lowest exchangeable calcium concentration in soil. The exchangeable calcium increased considerably in comparison to the values observed in the analyzed soil before the experiment was carried out. Probably this result is due to the contribution of the solubilization of $\mathrm{Ca}$ contained in the phosphate rock. The results are similar to the obtained by Stamford et al. (2006) studying sugar cane in a soil of the coastal tableland of the humid Zone of Pernambuco State, where higher values of exchangeable $\mathrm{Ca}$ were obtained in soil, when $\mathrm{P}$ and $\mathrm{K}$ rock biofertilizer was applied.

For exchangeable magnesium in soil, we observed a significant and positive effect when the $\mathrm{P}$ and $\mathrm{K}$ biofertilizers were applied. The best results were obtained with application of $\mathrm{K}$ biofertilizer in the highest rate (Figure
$3)$. The lowest values of exchangeable $\mathrm{Mg}$ in soil were obtained with application of soluble mineral fertilizers and in the control treatment. The highest values of exchangeable $\mathrm{Mg}$ in soil are explained by the solubilization of magnesium contained in the biotite rock used to produce the $\mathrm{K}$ rock biofertilizer (biotite), and by the effect of the sulphuric acid produced metabolically by Acidithiobacillus in the presence of elemental sulfur.

The research evidenced the possibility of the use of biofertilizers obtained from apatite and biotite plus elemental sulfur inoculated with Acidithiobacillus, specially due to the increasing availability of nutrients in soil. However, the rock biofertilizer with Acidithiobacillus may reduce soil $\mathrm{pH}$ and, therefore, its application is recommended to alkaline soils or to acid soils after liming. On acid soils, the biofertilizer should be mixed with organic compounds presenting high $\mathrm{pH}$, to maintain its acidity in a low level, as observed by Lima et al. (2007) using P and $\mathrm{K}$ biofertilizer in an acid soil of the Cariri added with earthworm compound $(\mathrm{pH} 7,9)$ in the lettuce crop. Ballestero et al. (1996) also showed the positive effect of the earthworm compound in the amendment of soil reaction.

The application of rock biofertilizers reduced soil $\mathrm{pH}$, specially when biotite is applied in higher amounts. After the melon crop, the rock biofertilizers showed potential to promote residual effect, evidenced by the higher concentration of available $\mathrm{P}, \mathrm{Ca}$ and exchangeable Mg in soil.

\section{ACKNOWLEDGEMENTS}

The authors are indebted to Conselho Nacional de Desenvolvimento Científico e Tecnológico (CNPq), and to Fundação de Amparo à Ciência e Tecnologia do Estado de Pernambuco (FACEPE) for financial support and fellowships.

\section{REFERENCES}

ANDRADE IP. 2007. Biofertilizantes de rochas fosfatadas e potássicas com enxofre inoculado com Acidithiobacillus na adubação da uva (Vitis vinifera L.) em planossolo do vale do São Francisco. Recife: UFRPE. 102p (Tese 
doutorado).

BALLESTERO SD; JORGE JA; NICOLINO CAC; FILLIETTAZ EVV; ONO RK. 1996. Efeito da compostagem na solubilização de rochas fosfatadas e potássicas. Biociências 2: 2-22.

BANIK S; DEY BK. 1982. Available phosphate content of an alluvial soil as influenced by inoculation of some isolated phosphatesolubilizing microorganisms. Plant and Soil 69: 353-364

BAR-YOSEF B. 1999. Advances in fertirrigation. Advances in Agronomy 65: 1-77.

BORTOLONL; GIANELLOC. 2008. Interpretação de resultados analíticos de fósforo pelos extratores Mehlich-1 e Mehlich-3 em solos do Rio Grande do Sul. Revista Brasileira de Ciência do Solo 32: 2751-2756.

COLLARD FH; ALMEIDA A; COSTA MCR; ROCHA MC. 2001. Efeito do uso de biofertilizante agrobio na cultura do maracujazeiro amarelo (Passiflora edulis $f$. flavicarpa Deg). Biociências 7:1-8.

DIAS SL; STAMFORD NP; BEZERRA AR; VASCONCELOS RB; 2005. Determinação de $P$ e $K$ disponível por método biológico com Aspergillus em função da adubação com biofertilizantes de rochas e fertilizantes solúveis em dois cultivos consecutivos com caupi. In: XV CONGRESSO DE INICIAÇÃO CIENTÍFICA DA UFRPE. CD ROM dos Anais do XV CIC da UFRPE. Recife.

EMBRAPA. 1997. Manual de Métodos de Análise de solo. 2. ed. Brasília: Centro Nacional de Pesquisa de Solos. 212 p.

EMBRAPA. 1999. Sistema Brasileiro de Classificação dos Solos. 1 ed. Brasília: Centro Nacional de Pesquisa de Solos. 412 p.

FARIA CMB; FONTES RR. 2003. Nutrição e adubação. In: SILVA HR; COSTA ND. Melão produção: aspectos técnicos. Brasília: Embrapa, p.40-50.

GARCIA JÚNIOR O. 1992. O enxofre e suas transformações microbianas. In: CARDOSO E; SAITO MT; NEVES MCP. Microbiologia do solo. Campinas: SBCS, p. 243-255.

HE ZL; BALIGAR VC; MARTENS DC; RITCHEY KD; KEMPER WD. 1996. Factors affecting phosphate rock dissolution in acid soil amended with liming materials and cellulose. Soil Science Society of American Journal 60: 1596-1601.

IPA. 2008. Recomendações de adubação para o estado de Pernambuco. 2 ed. Recife: Empresa Pernambucana de Pesquisa Agropecuária. $198 \mathrm{p}$.

KELLY DP; WOOD AP. 2000. Reclassification of some species of Thiobacillus to the newly designated genera Acidithiobacillus gen. nov., Halothiobaccillus gen. nov. and Thermithiobacillus gen. nov., International
Journal of Systematic and Evolutionary Microbiology 50: 511-516.

KUCEY RMN. 1983. Phosphate-solubilizing bacteria and fungi in various cultivated and virgin Alberta soils. Canadian Journal Soil Science 63: 671-678.

NAHAS E. 2002. Microrganismos do solo: produtores de fosfatases em diferentes sistemas agrícolas. Bragantia 61: 267-275.

LIMA RA. 2005. Biofertilizantes produzidos com fosfato natural e enxofre inoculado com Acidithiobacillus em solo de tabuleiro com baixo $P$ disponivel cultivado com cana-de-açúcar. Recife: UFRPE. 69p (Tese mestrado).

LIMA RCM; STAMFORD NP; LIRA JÚNIOR MAS; SANTOS CERS; DIAS SHL. 2007. Eficiência e efeito residual de biofertilizantes de rochas com PK com Acidithiobacillus em alface cultivada no Cariri cearense. Horticultura Brasileira 25: 402-407.

LOMBARDI MLCO; LOPES ES; CARDOSO EJBN; SILVA MTR. 1981. Eficiência da dissolução de três fosfatos naturais no solo, pela atividade microbiológica de oxidação de enxofre elementar. In: CONGRESSO BRASILEIRO DE CIÊNCIA DO SOLO, 18. Anais... Salvador: Resumos. Campinas, Sociedade Brasileira de Ciência do Solo p38.

MOURA PM. 2006. Uso de biofertilizantes de rochas com enxofre e Acidithiobacillus em Argissolo Argissolo Acinzentado do Vale do São Francisco cultivado com melão. Recife: UFRPE (Tese mestrado).

MOURA PM; STAMFORD NP; SANTOS CERS; NUNES GHS. 2007. Eficiência de biofertilizantes de rochas com Acidithiobacillus em melão no vale do São Francisco. Revista Brasileira de Ciências Agrárias 2:1-7.

NAHAS E. 1999. Solubilização microbiana de fosfatos e de outros elementos. In: SIQUEIRA JO; MOREIRA FMS; LOPES AS; GUILHERME LRG; FAGUIEN U; FURTINI NETO AE; CARVALHO JG. (ed). Interrelação fertilidade, biologia do solo e nutrição de plantas. Viçosa: SBCS p. 467-486.

RODRÍGUEZ H; FRAGA R. 1999. Phosphate solubilizing bacteria and their role in plant growth promotion. Biotechnology Advances 17:319-339.

SANCHEZ PA. 2002. Soil fertility and hunger in Africa. Science 295: 2019-2020.

SAS INSTITUTE. 1999. The SAS System for Windows. CD-ROM for Windows 32 bits.

SANTOS KS. 2002. Atuação de fosfato natural com adição de enxofre com Acidithiobacillus na solubilização de fósforo e no desenvolvimento de sabiá (Mimosa caesalpinifolia) em solo de tabuleiro. Recife: UFRPE. 72p (Tese mestrado).

SILVA FILHO GN; VIDOR C. 2000. Solubilização de fosfatos por microrganismos na presença de fontes de carbono. Revista Brasileira de Ciência do Solo 24: 311-329.

SOUSA VF; RODRIGUES BHN; ATHAYDE SOBRINHO C; COELHO EF; VIANA FMP; SILVA PHS. 1999. Cultivo do meloeiro sob fertirrigação por gotejamento no meio-norte do Brasil. Teresina: Embrapa.

SPERBER JI. 1958. Solution of apatite by soil microorganisms producing organic acids. Australian Journal Agricultural Research 9: 782-787.

STAMFORD NP; SANTOS PR; SANTOS CERS; FREITAS ADS; DIAS SHL LIRA JÚNIOR MA. 2007. Agronomic effectiveness of biofertilizers with phosphate rock, sulphur and Acidithiobacillus in a Brazilian tableland acidic soil grown with yam bean. Bioresource Technology 98: 1311-1318.

STAMFORD NP; LIMA RA; SANTOS CERS; DIAS SHL. 2006. Rock biofertilizers with Acidithiobacillus on sugarcane yield and nutrient uptake in a Brazilian soil. Geomicrobiology Journal 23: 261-265.

STAMFORD NP; SANTOS CERS; SANTOS PR; SANTOS KSR; MONTENEGRO A. 2005. Effects of rock phosphate, sulphur with and without Acidithiobacillus and organic byproducts on mimosa (Mimosa caesalpiniifolia) grown in a Brazilian tableland soil. Tropical Grasslands 39: 54-61.

STAMFORD NP; SANTOS CERS; STAMFORD JUNIOR WP; DIAS SL. 2004. Biofertilizantes de rocha fosfatada com Acidithiobacillus como adubação alternativa de caupi em solo com baixo P disponível. Analytica 9: 48-53.

STAMFORD NP; FREITAS ADS; SANTOS CERS; FERRAZ DS; MONTENEGRO A. 2003. Nitrogen fixation and growth of cowpea and yam bean in a sodic soil as affected by gypsum and sulphur inoculated with Thiobacillus and rhizobia. Tropical Grasslands 37: 11-17.

TEIXEIRA AHC. 2001. Informações agrometeorológicas do Pólo Petrolina. Petrolina: Embrapa.

VAN STRAATEN P. 2002. Rocks for crops: agrominerals of Sub-Saharan Africa. ICRAF, Nairobi, 388p.

VAN STRAATEN P. 2007. Agrogeology - the use of rocks for crops. Enviroquest, Cambridge, Ontario, Canada, 440p.

VILAR LD. 2003. Estudo da lixiviação bacteriana de metais presentes em lodo de esgoto sanitário. Araraquara: UNESP. 81p (Tese mestrado).

WHITELAW MA. 2000. Growth promotion of plant inoculated with phosphate-solubilizing fungi. Advances in Agronomy 69: 99-151. 